UNRAM Law Review is licensed under a Creative Commons Attribution 4.0 International License, which permits unrestricted use, distribution, and reproduction in any medium, provided the original work is properly cited. p-ISSN: 2548-9267 | e-ISSN : 2549-2365, Open Access at : http://unramlawreview.unram.ac.id/index.php/ulr

\begin{tabular}{c|c|c|c|c|}
\hline Volume & Issue & Page & April & p-ISSN: 2548-9267 \\
\hline 4 & 1 & $47-53$ & 2020 & e-ISSN : 2549-2365
\end{tabular}

\title{
Legal Consequences for Children who are Born in Unregistered Marriage in the Perspective of Christian Laws
}

\author{
Ruri Setyaningsih \\ Fakultas Hukum Universitas Airlangga \\ Email: rurisetya81@gmail.com \\ Tri Wahyu Anggraeni \\ Fakultas Hukum Universitas Airlangga \\ Email: saia_eni@yahoo.com \\ Debora Tri Hariyadi \\ Fakultas Hukum Universitas Airlangga \\ Email : 1994.deborahariyadi@gmail.com
}

\begin{abstract}
Aim of this study is to describe the marriage law for the Christian under marriage law and the legal consequence for the children born in a marriage that does not register as stipulated in the marriage law. Indonesia law acknowledges a marriage is legal if it conducted under the religious rules of the married couples and recorded under national law. This study aims to describe the marriage law for the Christian under marriage law and the legal consequence for the children born in a marriage that does not register as stipulated in the marriage law. Base on this study can be concluded that marriage is considered valid if it has been registered so as to have a valid legal effect, one of which the legal status of a child born of a legal marriage constitutes legal status as a legal child. While unregistered marriage resulting unrecognized legal status of the child so that child does not have legal status.
\end{abstract}

Keywords: Marriage; Register; Child.

\section{INTRODUCTION}

In a pure society, the marriage culture is simple, narrow, and closed, and in modern society, the marriage culture is advanced, broad, and open. The rules in a society or a nation are inseparable from the influence of culture and environment in which the community is located and the association of the people. It is influenced by the knowledge, experience, beliefs, and religion of the community concerned. Marital rules of the Indonesian people not only influenced by local customs but also influenced by the recognized religion, for example, Hindu, Buddha, Islam, Confucian, Catholic, and Christianity.

The religious aspect stipulates the validity of marriage, while the formal aspect is related to administrative aspects, namely registered by the Religion Affairs Office. Article 1 of Law Number. 1 of 1974 concerning Marriage states that marriage is an inner and physical 
bond between a man and a woman as husband and wife to form a happy and eternal family or household based on God. ${ }^{1}$

According to Salim HS in his book "Pengantar Hukum Perdata Tertulis (KUHPerdata)" The Purpose of Marriage is ${ }^{2}$ to form a happy and eternal family based on a God. This means that marriage are:

1. Lasts a lifetime;

2. Divorce requires strict conditions, and it is a last resort, and

3. The husband and wife help to develop themselves.

According to Subekti in his book "Pokok-Pokok Hukum Perdata" The requirements for a marriage to be valid are. ${ }^{3}$

a. Both parties must have reached the age specified in the law, namely for an 18-year-old for man and, for a 15-year-old for woman;

b. There must be free agreement between the two parties;

c. For a woman who has married must pass 300 days after the first marriage decision of separation;

d. There are no legal restrictions for both parties; and

e. For those who are still underage, there must be a permit from their parents or guardians.

According to the Population Administration Law, marriage is only permitted if the man is 19 years old, and the woman has to be 16 years. Determination of the age limit for a marriage is essential because marriage is an engagement agreement between a man and a woman as husband and wife must be conducted by those who are mature, both in terms of biological and psychological. ${ }^{4}$

Even though the marriage law has stipulated provisions in carry out a marriage, the actual practice showed that some marriage does not adhere to the marriage law. Marriage has legal consequences, particularly with respect to the children born in or as a result of that marriage. Therefore the marriage that does not perform under the law will also have a legal consequence to the children. This study will describe the marriage law for the Christian under marriage law and the legal consequence for the children born in a marriage that does not register as stipulated in the marriage law.

\section{METHOD}

This study is a normative juridicalresearch, that is a method that uses secondary data as the main source which obtained by library research. The problem approach used in this legal research is statute approach because there is a conflict between the laws and regulations that are related to the researchproblems. A statute approach is a legislative approach that is carried out by examining all laws and regulations relating to the legal issues being addressed ${ }^{5}$. The data used in this study were obtained from library research, as a data collection technique by utilizing various literatures in the form of legislation, books, scientific papers, papers, articles and other sources.

\section{ANALYSIS AND DISCUSSION}

\section{Marriage Law According to the Civil Code}

1 HS, Salim. Pengantar Hukum Perdata Tertulis (BW), Yogyakarta: Sinar Grafika, 2001, page. 61

2 Ibid, page. 62

3 Subekti, Pokok-Pokok Hukum Perdata, Jakarta: PT. Intermasa, 1985, p. 23.

4 Budi Prasetyo, "Perspektif Undang-Undang Perkawinan Terhadap Perkawinan Di Bawah Umur", Jurnal Ilmiah UNTAG Semarang, Vol. 6 No.1, 2017.

5 Dirdjosiswono, 1996, Pengantar Ilmu Hukum, Raja Grafindo Persada, Jakarta, p.6. 
The Civil Code applies to Europeans, Chinese, and Far Eastern or those who are subject to the Civil Code: ${ }^{6}$ IndonesiaCivil Code is an imitation of the Netherlands Civil Code, and it was applied to the Dutch in Indonesia in the era of Dutch colonization. After Indonesia independence, the government issued the Supreme Court Regulation No. 3/1963, which stated that the Civil Code is not as a law but as a document that only describes unwritten legal communities.

Taufiqurrohman Syahuri, in his book "Legislasi Hukum Perkawinan Di Indonesia" said that: ${ }^{7}$ The process of establishing Marriage Laws in Indonesia was inviting enormous attention from all levels of Indonesian society.

A Marriage certificate is proof of marriage. This certificate issued after the marriage fulfill all the requirement, namely the administrative requirement and registered in the Civil Registry Office. The presence of children from valid marriages or marriages that have been registered by both parents, prove that the child is a legitimate biological child of the father and mother. If the marriage not recorded, the status of the child is uncertain because the marriage of both parents is only valid before religion law.

\section{Marriage According to Christian Law}

"In Christianity, the concept of marriage from centuries has experienced developments and profound changes, and up to now are not entirely the same in various churches. "Ordonanti of Indonesian Christian Marriage applies to native Indonesians who are Christians in Java, Minahasa, and Ambon. " "In the following description, the provisions in Christianity which are considered important included: ${ }^{10}$

1. Marriage, according to Christianity, is only seen in civil relations.

2. The conditions for marriages are stipulated, among others: there must be an agreement between the bride and groom, the age limit for the bride and groom to be 18 years old, and for the bride to be 15 years old, with the possibility of requesting government concessions or dispensations.

3. Marriage procedures are determined as follows: before the marriage takes place, the relevant persons must inform their intention to the civil registry staff or religious leaders in the area of one of the parties to be married. After all conditions are fulfilled, the records officer or religious leaders confirm their marriage in public in the presence of two witnesses. The inauguration of the marriage may only take place after the tenth day of the marriage notification by the prospective bride, with the possibility of asking for concessions or dispensations.

4. Marriage annulment can only decided by a judge.

5. Marriage is declared dissolved.

6. Based on the same reasons for divorce, the husband and the wife are free to ask for the abolition of the obligation to live together.

7. The child out of wedlock can recognize as legitimate children

8. Marriage which takes place under this Ordinance or which is later subjected to this Ordinance, then this Ordinance continues to apply, even though one or both husband and wife then convert from Christianity.

Marriages conducted in both the Catholic church and the Christian church are legal even though they only performed under the church's marriage procedure. However, according to

6 Ibid, page. 71.

7 Taufiqurrohman Syahuri, Legislasi Hukum Perkawinan Di Indonesia, Op.cit, p.. 4.

8 Ibid, p..33.

9 Taufiqurrohman Syahuri, Legislasi Hukum Perkawinan Di Indonesia, Op.cit, p. 76.

10 Ibid, p. 76-79. 
Indonesia marital law, marriage is legal if the procession performed under the law of each religion and belief, and it meets other legal requirements of a marriage. In actual practice in society, some people conduct their marriages only under religious law and not registered at the civil registry office. Other practice, there are some only declare their marriages without performing their religious ceremonies. This action is contrary to Law No. 23 of 2006 concerning Population Administration. According to the Law of Population Administration, marriage must be recorded according to the applicable laws and regulations.

Marriage is a legal relationship between a man and a woman for a long time, which means that a legal marriage is only a marriage that fulfills the conditions stipulated in the Civil Code. ${ }^{11}$ Indonesia is a country that gives attention to marriages. Therefore it stipulate Indonesia Law No. 1 of 1974 concerning Marriage, which is legally formal as a national law governing marriages in Indonesia. This marriage law abolishes other provisions on marriage. Pursuant the provisions of Article 66 of the Marriage Law: ${ }^{12}$ As the effects of this law the provisions outlined in the Civil Code (Burgerlijk Wetboek), Indonesian Christian Marriage Ordinance (Huwelijk Ordonantie Christen Indonesiers S. 1933 No. 74), Mixed Marriage Regulations (Regulation op de gemengde Huwelijken S. 1898 (No. 154), and other regulations governing marriages to the extent outlined in this Act are declared invalid.

According to Hilman Hadikusuma in his book "Hukum Perkawinan Indonesia," Marriage law is: ${ }^{13}$ Before the presence of the Marriage Law in Indonesia, there were various marriage laws for different nationalities and different regions. Various marital laws were enacted before the enactment of the Law Number 1 of 1974 to the various nationalities and territories as follows: ${ }^{14}$

a. For Muslim Indonesians, there is a religious law that has been adopted into customary law.

b. For other Indigenous people, there is a customary law.

c. For Christians, there is the Huwelijks Ordonnatie Christen Indonesia (HOCI) S. 1933 Number 74.

d. For Chinese, both Foreigners and Indonesian who are of Chinese descent, the provisions of the Civil Code are subject to change.

e. For foreigners and other citizens of Indonesia of other foreign origins, their customary law applies.

f. For Europeans and citizens of Indonesia of European descentkk tuufjun n mbm mlv klkbvlngk mmnggdtvcuhyrhy (Indo) and to those in common with the Penal Code, Burgerlijk Wetboek (Civil Code).

\section{The Legacy of Marriage}

The influence of religion is even more, if we take a look at Article 2 of the Marriage Law which expressly states:

1. Marriage is lawful, as long it provided under the law of each religion andbeliefs.

2. Every marriage should be recorded in accordance with applicable laws.

The existence of Article 2 of the Marriage Law provides evidence that religion is the basis for determining whether a marriage is legitimate or not. Besides that, every marriage must recorded pursuant to applicable law. According to article 43 paragraph (1) of the Marriage Law

11 Kaharuddin, Nilai-Nilai Filosofi Perkawinan menurut Perkawinan Islam dan Undang-Undang RI Nomor 1 Tahun 1974 Tentang Perkawinan, Jakarta:Mitra Wacana Media, 2015, p. 4.

12 Afdol, Kewenangan Pengadilan Agama Berdasarkan UU No. 3 Tahun 2006 \& Legislasi Hukum Islam Di Indonesia, Surabaya: Pusat Penerbitan dan Percetakan Unair (AUP) Kampus C Unair, 2016, p. 85.

13 Hilman Hadikusuma, Hukum Perkawinan Indonesia, Bandung: Mandar Maju, 2007, p.4.

14 Ibid.,p.5. 
states, "Children born out of wedlock only have a civil relationship with their mother and their mother's family".

\section{Obligations for Marriage Registration}

In article 1 paragraph (15) of Law Number 23 of 2006 concerning Population Administration, Civil Registration is the recording of important events experienced by a person in the Civil Registration register at the implementing agency. Whereas population administration is a series of structuring and controlling activities in the administration of documents and population data through Registration Population, Civil Registration, management of Population Administration information and utilization of the results for public service and other sector development. The government population has the obligation and responsibility to organize the Population Administration nationally, which is carried out by the Minister with the authority to include:

a. Coordination between agencies in Population Administration matters;

b. Determination of the system, guidelines and standards for the implementation of Population Administration;

c. Publish Population Documents;

d. Providing guidance, supervision and consultation on the implementation of Population Administration affairs;

e. Management and presentation of National Population Data; and

f. Printing, publishing, and distribution of Population Document stamps.

According to Soetojo Prawirohamidjojo and Marthalena Pohan in their "Hukum Orang Dan Keluarga"said that ${ }^{15}$ : The Civil Registry Institute was formed with the aim to record (register) as completely and as clearly as possible $\mathrm{s}$ to provide the legal certainty regarding all events, for example:

1) Birth;

2) Recognition (of birth);

3) Marriage and divorce;

4) Death;

5) Permit to marry.

According to article 8 of the Population Administration Law state that:

1) The Implementing Agency carries out Population Administration affairs with obligations which include:

a. Register Population Events and record Important Events;

b. Providing equal and professional services to each resident on reporting on Population Events and Important Events;

c. Publish Population Documents;

d. Document the results of resident registration and civil registration;

e. Ensure the confidentiality and security of data on Population Events and Important Events; and

f. Conduct verification and validation of data and information submitted by residents in serving Population Registration and Civil Registration.

2) Obligations as referred to in paragraph (1) letter a for the registration of marriage, divorce, divorce, and referral for residents who are Muslim at the district level are carried out by recording staff at the Office of Religious Affairs of the Sub- District.

3) Civil Registration Services at the sub-district level are carried out by the Implementing Agency with the authority to issue a Civil Registration Deed.

15 Soetojo Prawidohamidjojo \& Marhalena Pohan, Hukum Orang Dan Keluarga, Surabaya: Pusat Penerbitan dan Per cetakan Unair (AUP), 2008, p. 6. 
4) Obligations as referred to in paragraph (1) for the requirements and procedures for the Registration of Important Events for Residents whose religion has not been recognized as a religion based on the provisions of the legislation or for believers based on the legislation.

5) Further provisions regarding the Technical Implementing Service Unit of the Implementing Agency as referred to in paragraph (3) and the priority of its establishment shall be regulated by Government Regulation.

According to Soetojo Prawirohamidjojo and Marthalena Pohan in their book "Hukum Orang dan Keluarga" said that ${ }^{16}$ : if all the citations from the list of Civil Registry are in accordance with the list, then the contents must be trusted until the civil suit is filed, or criminal judgment stating the quote is false.

\section{Legal status of the Children}

According to the Law of Population Administration, a legitimate child is a child born in or as a result of a legal marriage. ${ }^{17}$ Meanwhile, Moch. Isnaeni in his book "Hukum Perkawinan Indonesia" comented regarding the legitimate children is: $:^{18}$ One of the goals of marriage is to regeneration so that the continuity of the community can still runs without stopping. Children from a marriage often make family relationships more reliable and closer, so does the sense of responsibility of each partner become strong.

The legal status of a child will depend on the status of a parent's marital status. A legal status of marriage gives children born in or as a result of that marriage as legitimate children. On the contrary, if the marriage performed not adhere to the requirement in marriage law, then the children born in or as a result of that marriage cannot entitled legitimate children. As a result of being born from an illegitimate marriage, the child only has a civil relationship with his mother and his mother's family.

\section{CONCLUSION}

The Indonesian marriage law acknowledges that marriage is legal if it performed under religion law and registered at the Office of Religious Affairs. This provision apply to all religion in Indonesia, including the Christian.

The status of marriage under national law has legal consequence to the legal status of children that born in that marriage. Children born in or as a result of marriage that have a legal status entitled legal status. On the contrary, children born in unregistered marriage do not entitle a legal status.

\section{Bibliography}

Books:

Afdol, 2016, Kewenangan Pengadilan Agama Berdasarkan UU No. 3 Tahun 2006 \& Legislasi Hukum Islam Di Indonesia, Surabaya: Pusat Penerbitan dan Percetakan Unair (AUP) Kampus C Unair.

Dirdjosiswono, 1996, Pengantar Ilmu Hukum, Jakarta: Raja Grafindo Persada.

Hadikusuma, Hilman, (2007), Hukum Perkawinan Indonesia, Bandung: Mandar Maju.

HS, Salim. (2001), Pengantar Hukum Perdata Tertulis (BW), Yogyakarta: Sinar Grafika.

16 Soetojo Prawirohamidjojo dan Marthalena Pohan, Hukum Orang Dan Keluarga, Surabaya, Pusat Penerbitan dan Percetakan Unair (AUP), 2008, p.7.

17 Soetojo prawirohamidjojo, Pluralisme Dalam Perundang-undangan Perkawinan Di Indonesia, Surabaya: Pusat Pe nerbitan dan Percetakan Unair (AUP), 2012, p..104.

18 Moch. Isnaeni, Hukum Perkawinan Indonesia, Surabaya: PT. Refika Aditama, 2016, p.. 117. 
Kaharuddin, (2015), Nilai-Nilai Filosofi Perkawinan menurut Perkawinan Islam dan UndangUndang RI Nomor 1 Tahun 1974 Tentang Perkawinan, Jakarta:Mitra Wacana Media.

Marhalena Pohan, Prawidohamidjojo, Soetojo, (2008), Hukum Orang Dan Keluarga, Surabaya: Pusat Penerbitan dan Percetakan Unair (AUP).

M. Hadjon, Philipus, dkk, (1994), Pengantar Hukum Administrasi Indonesia, Surabaya: Gadjah Mada University Press.

Prawirohamidjojo, Soetojo, (2012), Pluralisme Dalam Perundang-undangan Perkawinan Di Indonesia, Surabaya: Pusat Penerbitan dan Percetakan Unair.

Prawirohamidjojo, Soetojo,dan Pohan, Marthalena, (2008), Hukum Orang dan Keluarga, Surabaya: Pusat Penerbitan dan Percetakan Unair (AUP).

Subekti,(1985), Pokok-Pokok Hukum Perdata, Jakarta: PT. Intermasa.

Syahuri, Taufiqurrohman (2015), Legislasi Hukum Perkawinan Di Indonesia, Jakarta: Prenada Media Group.

Law and Regulations:

Undang-Undang Nomor1 tahun 1974 tentang perkawinan.

Undang-Undang Nomor 23 tahun 2006 tentang Administrasi Kependudukan.

Peraturan Pemerintah Nomor 9 tahun 1975 Pelaksanaan Undang-Undang Nomor 1 tahun 1974 tentang Perkawinan.

Peraturan Presiden Nomor 25 tahun 2008 tentang persyaratan dan Tata Cara Pendaftaran Penduduk dan Catatan Sipil.

Journal articles:

Prasetyo, Budi. 2017. "Perspektif Undang-Undang Perkawinan Terhadap Perkawinan Di Bawah Umur”, Jurnal Ilmiah UNTAG Semarang, Vol. 6 No.1.

World Wide Web:

http://hukum.unsrat.ac.id/ma/kompilasi.pdf 